\title{
COMMENT PROFITER DE LA BÊTISE? OR MODERNIZING THE DICTIONARIES OF INDONESIAN LANGUAGES
}

\section{James Siegel}

"Rien ne m'avait préparé particulièrement à une entreprise de ce genre....Rien?"

Émile Littré, Comment j'ai fait mon dictionnaire

Hoesein Djajadiningrat, I was told, spent years and years working on his AtjehscheNederlandsch Woordenboek. The final dozen months he spent on an island off the Acehnese coast. It took a special envoy to pry the work out of his hands. Approximately forty years later, reading Acehnese literature and looking up a word, I would find the sentence I was having difficulty with given as an example. This happened often; I could not understand how the author of the dictionary had me in mind. It was only when I saw the pattern of his examples that I found the answer. Djajadiningrat chose the most difficult sentences of Atjehnese literature. Encountering one of these sentences in a text, any reader would be likely to drop it and turn to the dictionary. These sentences were difficult, I believe, not only for those for whom Acehnese is a foreign language, but even for Acehnese themselves because the usages strained the ordinary sense of the word or because the sentence as a whole was idiomatic or perhaps even unique in its configuration. Djajadiningrat had obviously read carefully. I wondered why he had translated so little from Acehnese. I thought I found the answer when I looked again at his examples. For instance under $s a$, the Acehnese for "one," there is this from the Hikajat Potjoet Moehamad:

Keu neujoë seutet ngòn Malém Poetéh, geudoebang meutjéh geubileuëngsa.

hij liet ook MP halen, het uitmuntende zwaard, dat als eenig (als onvergelijkelijk) werd beschouwd (ie, die onvergelijekelijk was in de hanteering wan het zwaard). 
The example is typical in that Djajadiningrat approximates the rhythm of the Acehnese line, which is broken in the middle, one phrase answering the other. The pattern of the hikajat is to break the line again, dividing the two phrases once more. Despite the absence of a comma, this is the case in our example. In ordinary speech one would invert the syntax to form a single phrase. Djajadiningrat's Dutch manages to reproduce the prosodic divisions by modifying everyday Dutch in a similar fashion. It is amply evident that Djajadiningrat heard Acehenese with an acute ear.

But the lexicographer's Dutch translation has additions that were not necessary in the original. The translation renders the sense of the phrase by means of emendations twice inserted into the sentence. In effect, the author of the dictionary adds a supplementary voice when he explains what "the Acehnese," if we can take that term in a double sense, says. In the first parenthesis he is the lexicographer giving a supplementary sense to $s a$, "without equal." Then he is the interpreter of the text, saying in what respect the sword is without parallel. It may be that anyone who knew Acehnese well would feel compelled to add similar remarks in order to make the sense clear. But it is also evident that Djajadiningrat did so in a way that shows the voices are disparate. The reproduction of the rhythm makes it seem as though one language could speak through a second, and as if one were hearing an Acehnese voice in the translation. But Djajadiningrat breaks in with his comments in the very midst of the sentence. No one should be fooled into thinking he hears Acehnese in Dutch just because he seems to do so.

We no longer think that there is a voice of the lexicographer. In Samuel Johnson's time it was, of course, different. There it was a question of Johnson's unparaphrasable irony; only Johnson could have said that. If I met Djajadiningrat, I would not recognize him by his voice. Yet there is a distinct identity that pervades his dictionary. One starts to wonder how he was able to chose his examples so well. One might attribute that skill to his cultivation and carefulness, but more is at work here. One wonders how he could understand what he read so well. Frequently he explains a word on the basis of a particular context. We have an example in his second intervention, cited above. Unlike Johnson, he does not speak from experience in life, but from a profound knowledge of what he read. To read this way he must have loved Acehnese literature. And yet when he inserts himself into the middle of Acehnese sentences, it is an intrusion; someone who comes from someplace indefinite and quite outside the text here introduces disconcerting foreign sounds.

To do so as "the lexicographer," the knower of words, makes it appear that there are equivalents of words between languages, and it is the task of the lexicographer to furnish them. But when Djajadiningrat interrupts Acehnese rhythms with the Dutch equivalent, he makes us hear another voice, one in Dutch that does not match the Acehnese. I regret his interventions, and yet I appreciate them, not only for their aide but also because, taken in the aggregate, they demonstrate an eagerness to respond that makes one feel the power of Acehnese. Djajadiningrat could not wait. He heard something, and he indicates it in his reproduction which begins as mimicry rather than transformation. At the moment when he speaks himself, however, he shows how his own position relative to the text alters in time; beginning as the listener inside the text, he inevitably returns to his identity as a foreigner, surrounded by strange sounds.

Djajadiningrat's citations do not have dates attached, unlike those of the OED, for instance. They are not given in order to shed light on the evolution of the word. He sometimes gives definitions of a word's meaning that might be found only once in Acehnese literature. One thus can hear a word in its singularity when he cites a phrase, which seems contrary to the practice of most dictionaries. He justified this method, no doubt, by thinking 
his readers would be the translators and readers of Acehnese literature, interested precisely in these particular phrases. The reader of Acehnese is grateful to Djajadiningrat for making a certain entry into the language possible. But definitions of this sort are not appropriate. A person who refers to this dictionary because he wishes to speak the language will only be able to use the word in the sense Djajadiningrat sometimes gives it by quoting the phrase Djajadiningrat quoted. The Acehnese language thus remains present in the ear or the mind, but as a foreign entity, not merely untranslatable for the foreigner, but also not useful for him if he wishes to to function as a speaker or reader of Acehnese. Indeed, this is not a dictionary of great use for anyone who wants to speak Acehnese as opposed to appreciating it. One is left with a language that speaks to one, that one hears as it fades away, that retains its immutability even when one translates. Writing a dictionary that shows the impossibility of translation, Djajadiningrat makes evident the gap between separate languages and between separate voices.

There are other dictionaries of Indonesian languages which create the same effect in different ways. I think, for instance, of Pigeaud's dictionary of Javanese. This dictionary lacks illustrations. Only those with a strong knowledge of Javanese can usefully have recourse to it, for Pigeaud's Javanese and Dutch function principally as reminders of what one has temporarily forgotten. All the work of translation goes on in the mind of the reader. Such a dictionary is meant to accompany the reading of the Ngarakertagama, perhaps. Pigeaud, who of course edited this grand work (one does not speak of translating it) furnished an English word for more or less every Javanese word in the original and then added volumes of annotations. Looking at the English, no sentences form. It is up to the reader to see that that this is as far as Javanese can penetrate into English. One realizes only paraphrase is possible in the act of translation. The original remains something which one is sure exists, but which can never be reached unless, of course, one plunges back into the Javanese.

Such dictionaries are to my taste. They contrast with the vocabularies which are based on an assumption that translation is a fairly direct process. The later are useful dictionaries to those who want to speak the language. They encourage a person to think that he will be able to generate sentences in a foreign language. One says a few words, more or less respecting the rules of syntax and grammer, and those words elicit a response. In the end, people who use such dictionaries believe there are really equivalents between languages, that relying on aides such as dictionaries enables one to communicate intentions and ideas even when they are formulated first in another language. It is a relief. But, of course, in practice mistakes occur. It may not be the fault of the dictionary. In my case, it rarely is. But my mistakes in foreign languages live in my memory much longer than my successes. I think of the banal error I made in 1962 when, in Kotaradja, now Banda Atjeh, the chief-of-police handed me my driver's licence saying, "Hati-hati, disini jalan kiri," (be careful, here we drive on the left). Proud of my newly-gained Indonesian, I told him, "Ngak apa-apa. Saja suka jalan $k a k i$," or, "Don't worry, I like to walk." I translate these phrases into English here not because the reader does not know Indonesian, but because only then is the joke apparent. I wanted to impress the chief-of-police-the first I had ever met-and I eagerly told him something about myself that is still true and that displayed my ignorance. In 1995 in Paris, in my bad French accent, I asked a grocer for some thyme (thym). He handed me a can of tuna (thon). That summer in a small village in l'Aveyron, I tried again. The old woman in the little store asked me, "red or blue?" Never having seen either variety and wanting to know what I would get, I said, "red." She handed me a postage stamp (timbre). I am sure I will 
remember my rapport with these people far longer than my connection to others with whom I have exchanged many more words and more accurately.

It is not that I am fond of embarrassment or infallibly remember it. It is rather that I am struck by the power of my language. It is not equivalence that evokes response. It is the assumption, in the case of the old woman, for instance, that I was speaking language and that I had asked for something within the confines of her tiny store and the usual interactions that take place inside that space. She thought I meant something I did not, and so I got a postage stamp, always useful for another message. It was not my intention but something else, nonetheless attributed to me, that made her give me the stamp. It is a bit different with the chief-of-police. He had already given me my license. I doubt very much that he still remembers what I said, much less remembers me. But I recall the incident after thirty-four years. It is because, once again, it was not "me," the person who says what he means, the person who can be equated with his intentions, who became involved in this brief conversation, but another "me," one I do not know but who accompanies me, particularly when I speak, and who becomes visible when I make errors. This double of myself is a repository of language that the other me is not aware of possessing. He becomes apparent in the presence of someone else who recognizes something in me hidden from myself.

Most dictionaries are devoted to preventing this uncanny doubling. The dictionaries of French-English and English-French are not. I cannot blame them for the errors I have related. But they are so replete with inaccuracies that one begins to think that the lexicographers shared Djajadiningrat's concern to guard and illustrate how inadequate one language must always be as a device to explain the meanings inside another language. It makes of French and English what one had till recently thought they were: separate languages mutually understandable only at a great cost. But this is not the common assumption of translation today when English seems to many to be perfectly adequate counterpart to any language of the world and when the exchangability of languages has become an assumption accompanying the augmented speed of communications.

Dictionaries that rely on everyday speech rather than literature for their examples seem to further this trend unless, like the English-French, French-English dictionaries, they refuse to be accurate. It seems to me remarkable, then, that a dictionary of a regional language has appeared that contains for its examples perhaps as many quotations from newspapers and popular writing as from literature and that, while no doubt very useful for those who want to speak the language, seems to me to respect the gap between languages. I refer to Gerard Moussay's excellent Dictionnaire Minangkabau Indonesien-Français. I give one of Moussay's examples under saléro III:

Bujang nan kini lah manuruikkan saléro, inyo dapek céwek nan peréman pulo, di sinan basobok kalorok sakutiko, kaduonyo ampia tiok ari raun dai kampnuangyo, tujuan tantu ka kota pulo.

Bujang s'est mis à fréquenter, et il a une copine qui est aussi très délurée; c'est avec elle qu'il file le parfait amour; presque chaque jour ils quittent tous les deux le village pour aller faire un tour, et ils s'en vont bien sûr vers la ville.

I lack experience, but it strikes me that "filer le parfait amour" in Minangkabau is as different from the French as it would be from the English equivalent. "Saléro" means "appetite" or "desire"; it refers as much to taste as to sex and has a natural or 
physiological resonance which colors the phrase translated as "file le parfait amour." In the sentence, the boys of today are said to "follow their desires" and thus to meet girls as wild as themselves (paréman pulo) who please them with the result that almost every day they go out and head for the city. I do not offer this English approximation as a correction to Moussay's French, all the more so as I do not know Minangkabau. But it is evident that this popular novel speaks of the bad habits of today when desire has a free rein. This, from another perspective, could be the opening of the possibility of love. I am sure that Moussay's translation is as close as possible to the original. But the overlay of French on top of Minangakabau brings out a dimension which is present in Minangkabau but which also gives the passage a tonality necessarily different not only from the original, but also from the English rendering. An English reader of this dictionary has the possibility of seeing multiple dimensions appear as he hears "parfait amour," "perfect love" and "basobok kalorok sakutiko," each of which conceals rather than illuminating the others.

It is in fact one of the strong virtues of the Dictionnaire Minangkabau Indonesien-Français that it is trilingual, though the examples are translated only into French. It indicates the multiplicity of sorts of users Moussay has in mind, and thus contrasts with the methods and perspectives of the Dutch language lexicographers we have cited above. It also lets us see in short compass how tonalities necessarily differ between languages. I choose at random:

$\begin{array}{llll}\text { Minangkabau } & \text { Indonesian } & \text { French } & \text { English } \\ \text { mati } & \text { mati } & \text { mourir } & \text { die } \\ \text { rusak } & \text { rusak } & \text { brisé } & \text { broken } \\ \text { runuik } & \text { runut } & \text { trace } & \text { trace } \\ \text { piliah } & \text { pilih } & \text { faire un choix } & \text { choose } \\ \text { pespa } & \text { vespa } & \text { vespa } & \text { vespa } \\ \text { bapenda } & \text { berputar } & \text { tourner } & \text { turn } \\ \text { pakai } & \text { pakai } & \text { utiliser } & \text { use }\end{array}$

I have added the English tropes to exaggerate the sense that, beginning with Minangkabau, the translations go in various directions. Between the brusque finality of "mati," the sense of expiration of "mourir" and the violence of "die" there are unbridgeable gaps. The Indonesian "berputar" turns in registers missing from English which I can ignore unless I have to consider whether I am absolutely certain tourner and "turn" are perfect equivalents. This difference between languages is well known, of course. When reading a bilingual dictionaries, one tends to absorb or forget that difference because at least one of the languages speaks to the reader. There are only two actors communicating in this case, a speaker and a hearer, or a writer and a reader. One understands the other. But in a trilingual dictionary the Minangkabau word "runuik," which becomes "trace" in both French and English, can no longer speak to me. It avoids me as it flys into a language where "trace" becomes involved in questions of language rather than questions about crime and detection.

The pleasure of Moussay's trilingual dictionary comes from reading both the definitions and the examples:

kalua inyo dari dalam tangsi, dapek karajo jadi polisi, dek kuaik tolong Tuan Residen, manjadi komandan di Tanah Abang, kumandan polisi maso itu. 
quand il sortit de prison, il obtint le travail de policier, et comme il aida beaucoup Monsieur le Résident, il devint alors commandant de Police à Tanah Abang. (polisi)

Of course one wants to know more. But frequently it is sufficient to have these Minangakabau phrases, which give the feeling that there are stories to be heard and that here one sees a bit of Tanah Minangkabau. One has the feeling that one recognizes something:

bangkai taraktor ko io sangaik barek tampak dek den, tapi den liek sopirnyo murah sajo mamuta-muta sakandak atinnyo; kakaguman rang kampuang sabana tagugah.

la masse de ce tracteur m'apparaissait imposante, mais je m'aperçus que le conducteur faisait pirouetter cet engin à son gré et avec une grande facilité; ce qui suscita un véritable émerveillement chez les gens du village. (puta I)

The sense of recognition here depends on knowing beforehand the difference between villagers and city dwellers and the attraction of machinery, both concepts which fall somewhere between cultural categories and stereotypes. Once we recognize these underlying perceptions, we can feel ourselves there, very near the machinery, as observers perhaps or even as actors. This putting ourselves in the scene is absolutely contrary, however, to the more frustrating experience readers undergo when they encounter the gap between the languages that Moussay emphasizes.

We know that we cannot translate and we translate nonetheless. Why? In some way we find ourselves in the scene, whether we are convinced we are rightly there or not. We find ourselves both "here," wherever we might be at the moment, and "there," in the text in front of us. But it is this doubling that tells us how we got there. It is the moment of surprise that matters. I know a woman who spent two years in Indonesia, left, and did not speak the language for seventeen years, by which time she had, naturally enough, forgotten it. After seventeen years, she disembarked from the plane in Jakarta and began once again to speak. Why could she speak in Indonesia and not in the United States? It needed practically nothing to restore her language. Someone said something to her, doubtless, "selamat datang," "welcome," and she answered in their language. She spoke in order to answer. But she was addressed because whoever said "selamat datang" thought she would understand.

They were mistaken, but they were also correct. She spoke not knowing that she could do so. It was not the person in control of her language who answered. It was someone who, hearing, seemed to have a response pulled out of her. She was, we could say in English, beside herself. Doubtless she answered first with a mere formula, "terima kasih," "thank you." But having already had an exchange, she had the feeling she could speak. This is not a miracle. The feeling one can speak or that one has something to say is not necessarily accurate, as anyone who recalls learning a language knows. If I can elicit an exchange, I sometimes thinks I know the language, only to find with the next utterance that this confidence was misplaced. But even in my own native language this is the case. However, once I feel I can engage in an exchange, I continue often to learn the language. And why? Is it not that I sense that the other, in whatever form it appears, feels he can speak? And this is more conventionally the case in Indonesian than in European languages. One thinks, for instance, that the early form of " $I$ " was "hamba," "slave"; that the first-person is therefore the possession of the second and must take his language from the other. This concept opposes the American conviction that "I" generates his own language. The other, the stranger, determines one's language in Minangkabau. And the other is convinced one can speak. Communication begins with a bêtise. 
And after? One is a repository of language. One "knows" that from being addressed. But this entity who has the language is largely unknown to the second inhabitant of the same body. In order to find out what one did not know one knows, one starts to follow the traces and he arrives in certain scenes. It is the double who arrives on the other side of the gap. "Comment $j^{\prime}$ ai fait mon dictionnaire," Littré said. He said it first to himself. He presents himself as the writer and the subject in the title. The title has no punctuation; it could as well be a question Littré asked himself. Indeed, Littré was fond of posing questions to himself in the presence of readers, as in the exordium to this piece which forms the first sentence of his text. Judging from this, Littré never exited from the doubling inherent not only in lexicography, but in all linguistic practice. Starting from this duplication, one makes a dictionary. Nothing prepared him for his long enterprise. He merely stumbled onto the project when he was over forty after having occupied himself with the study of Greek medicine. It was a question, he says, of "une occassion fortuite" and also of "mes vastes appétits." 1 He speaks further of the good fortune he had and of other instances of chance. He stumbled onto the dictionary, picked himself up, and felt compelled to follow through. It was a form of bettise. I imagine that all the best dictionaries are written in this way. One feels one knows something one knows one does not know. Mere accident tells one so. Gérard Moussay lived in Minangkabau seventeen years. No doubt it took him that long to get over the betise. We are grateful.

\section{References}

R.A. Hoesein Djajadiningrat, Atjèhsch-Nederlandsch Woordenboek met Nederlandsch-Atjèhsch Register (Batavia: Landsdrukkerij, 1934).

Émile Littré, Comment j'ai fait mon dictionnaire (Paris: Editions Philippe Picquier, 1995). (Originally published in 1880).

Gérard Moussay, Dictionnaire Minangkabau Indonesien-Français (Paris: Editions L'Harmattan and Association Archipel, 1995).

1 Émile Littré, Comment j'ai fait mon dictionnaire (Paris: Editions Philippe Picquier, 1995), pp. 11, 10. (Originally published in 1880). 
